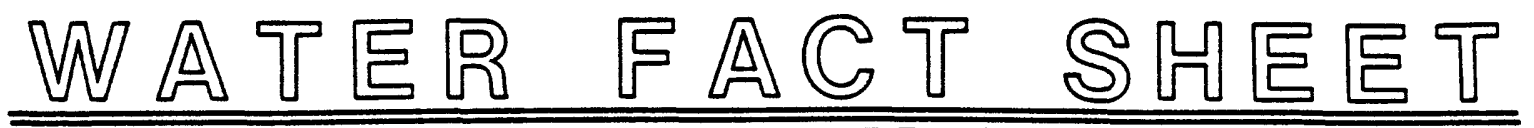

U.S. GEOLOGICAL SURVEY, DEPARTMENT OF THE INTERIOR

\title{
GROUND-WATER RESOURCES \\ OF HONEY LAKE VALLEY, \\ NEVADA AND CALIFORNIA
}

\section{BACREROOND}

Honey Lake Valley is a 2,400-square-mile drainage basin that straddles the Washoe County, Nev.-Lassen County, Calif., Stace line north of Reno. Streams fed by precipitation flow toward the center of the basin. Some of the streamflow infiltrates the land surface to become ground water and, in all but the driest years, some accumulates on the valley floor to form Honey Lake. Most water in the basin evaporates or is used by plants before it reaches the ground-water aquifers or the lake. (Aquifers are water-bearing rocks or sediments that can yield usable quancities of wacer to wells or springs.)

Principal aquifers that underlie Honey Lake Valley are layered sedimencary deposits (sand, gravel, sile, and clay) and fractured volcanic rocks. Most of the wacer withdrawn by wells is used to irrigace crops in the basin. Some wacer is withdrawn for municipal and induscrial use, primarily in the Susanville, Calif., area. Some water is withdrawn for domestic use elsewhere in the basin and for military purposes at the Sierra Army Depot at Herlong, Calif.

\section{IHE FROBLE:}

The Reno-Sparks area in western Nevada is one of the fastest-growing populacion centers in the United states. Nearly all economically available surface and ground wacer in the vicinity already has been allocaced, and more distant basins are being soughe to supply the water needed for continued growth. The Nevada part of the Honey Lake aquifer is being considered as a possible source of water for Reno and Sparks, and for the unincorporated areas of southern Washoe County. Therefore, a careful assessment of the availability of long-cerm wacer supply from the entire Honey Lake basin and a better understanding of the resource is needed.

Several major questions to be considered include: How much ground water is available in the aquifers that underlie Honey Lake Valley? How is it consumed? How is it replenished? What are the physical Iimitations of ground-wacer availabilicy? What are the potential effects of the transfer of ground water from one basin to another? What are the potential effects of new development on the aquifers? These questions cannot be answered without an accurate, decalled evaluacion of the wacer budget and flov systen of the basin.

\section{WHB BONET LAKE VALTEI STODY}

The U.S. Geological Survey (USGS), in cooperation with the Nevada Division of Water Resources and the California Department of Water Resources, has begun an investigation of the water resources of Honey Lake Valley. The 3-year study, which began in April 1987 , is divided into three overlapping phases: (1) background evaluation and daca collection, (2) field studies and data analysis, and ( 3 ) incerpretation and report preparation.

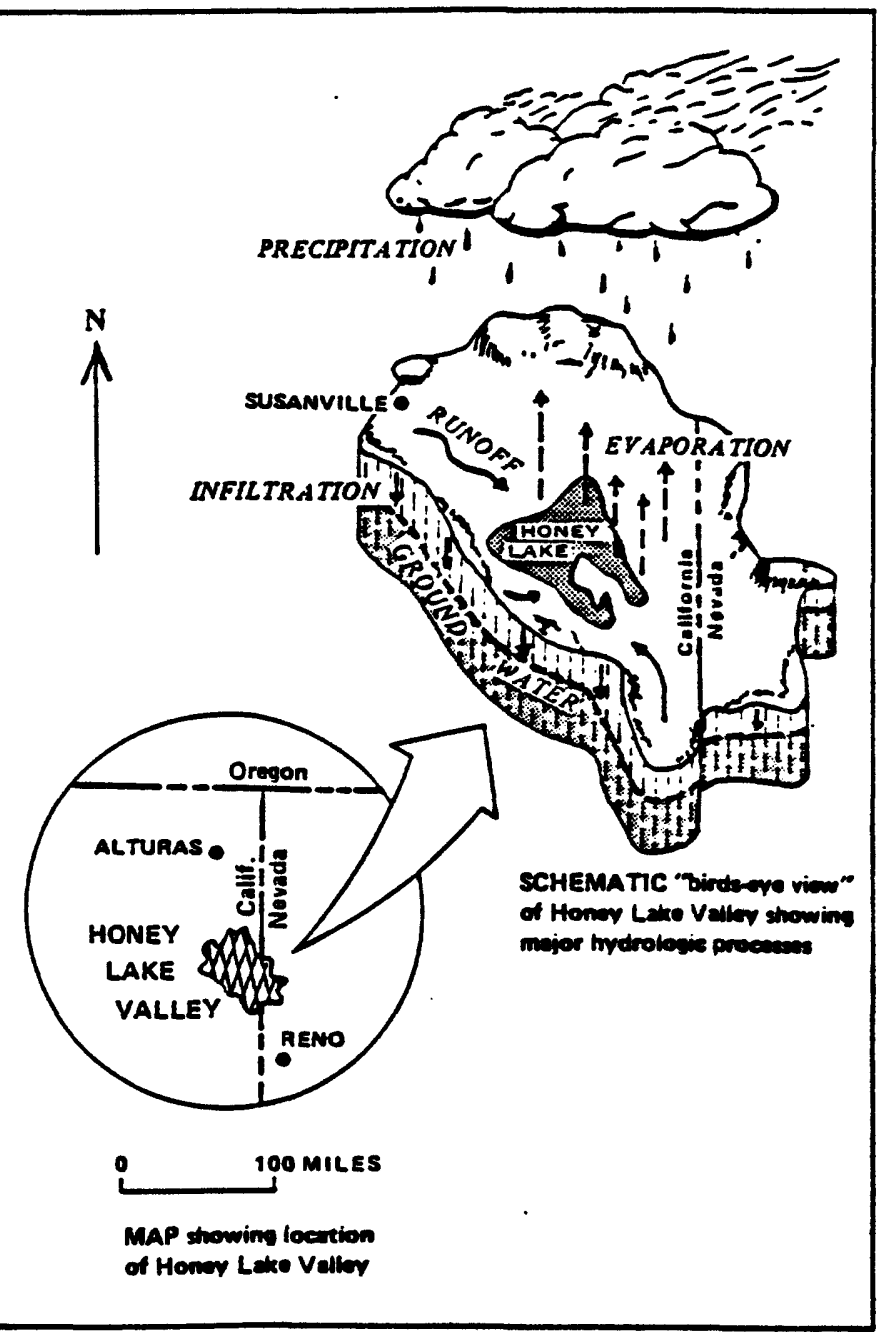



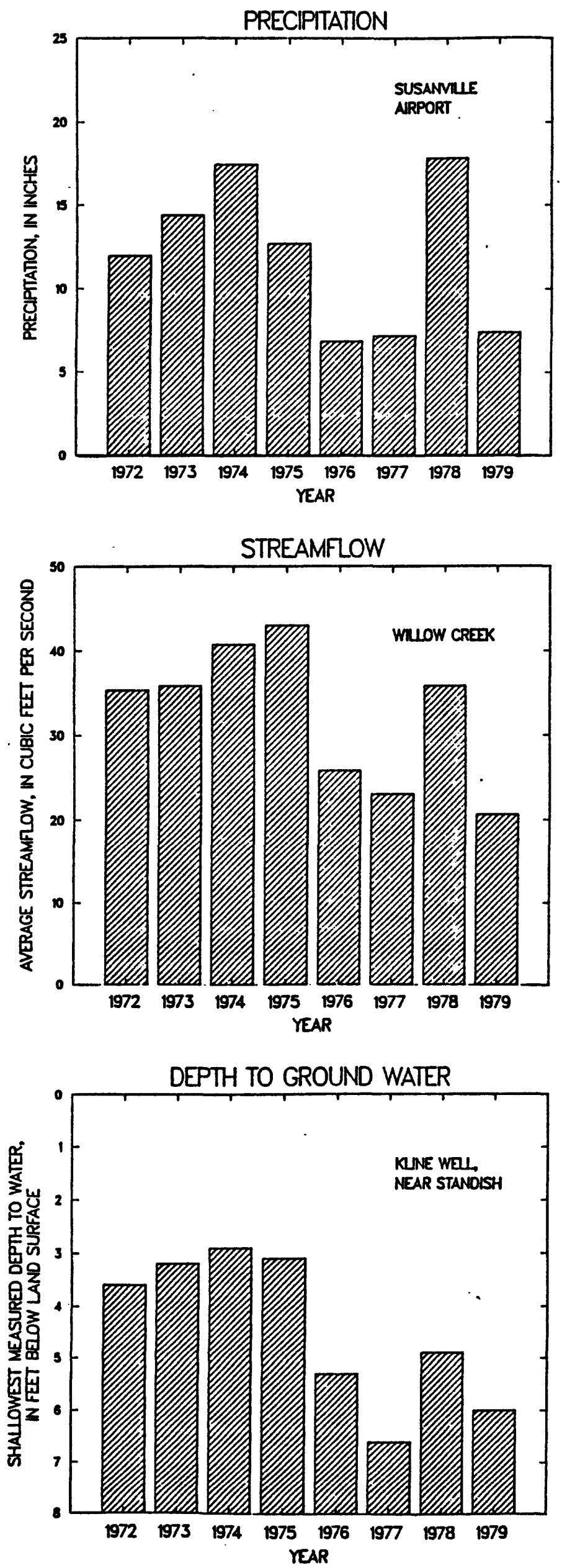

Scientists of the USGS are making periodic measurements of precipitation, streamflow, and wacer levels in wells to learn about how water is stored in and moves through the aquifers in Honey Lake Valley. Measurements of precipitation indicate how much water comes inco the area. Some water evaporates and some is used by planes. The rest accumulates on and flows over the land as surface water (lakes and streams) or infiltrates the land surface to become ground water. In Honey Lake Valley, much of the streamflow infiltrates before it reaches the valley floor. Measurements of streamflow indicace how much water is available for replenishing the aquifers in differenc seasons, years, and locations and how fast it seeps into the ground. Measurements of water levels in wells provide a record of changes in the amount of water scored underground and an indication of the effects of withdrawals.

Test-well drilling and geophysical surveys (gravity, lectromagnetic, and seismic) provide information about types of aquifer materials and cheir excent. Geologic feacures are analyzed because they control races and directions of ground-wacer flow. Soils maps are used to help decermine rates of infil: tration at land surface. Vegecacion is mapped in the field and by interpretation of remote-sensing (satellite) data to provide estimates of the quantities of water consumed by crops and native plants.

A compucer model will be used to decermine and quantify components of the ground-water flow system for Honey Lake Valley. The model is a mathemacical representation of the natural flow system. Results obtained from the model will be compared with field observations, measurements, and estimaces to test and improve our understanding of the hydrologic system, to guide further data collection, and to make preliminary estimates of the possible effects of futuro development and water-managemenc altermacives.

Information from the scudy will be useful to state and councy wacer managers and planners, wacer users, public officials, and the general public for planning future developmene. The study will describe the components of ground-water flow and the charac. teristics of aquifers in Honey Lake Valley and the direction and magnitude of ground-water flow at the Nevada-California border.

For information about water planning and managenent, contact:

Nevada Division of Water Resources

Capitol Complex, 201 S. Fall Sereet

Carson City, NV 89710

California Department of Wacer Resources

Northern Discrice

P.0. Box 607

2440 Main Street

Red Bluff, CA 96080

For more information about the Honey Lake Valley study, contact:

District Chief

U.S. Goological Survey

705 N. Plaza Street, Rm. 224

Carson CIty, NV 89701

E. H. Handman

Carson City, Nevada

Open-File Report 88-306 1988 